\title{
Improving Iranian EFL Learners' Writing through Task-based Collaboration
}

\author{
Nafiseh Hosseinpour (Corresponding Author) \\ Department of English Language, Falavarjan Branch, Islamic Azad University, Isfahan, Iran \\ Reza Biria \\ Department of English Language, Khorasgan (Isfahan) Branch, Islamic Azad University, Isfahan, Iran
}

\begin{abstract}
A large body of research has examined the interaction of oral and written language in formal educational context. Language practitioners and researchers have also taken up the sociocultural approach to language learning and emphasized the need for composition teachers to promote a social atmosphere in classrooms through collaboration. Accordingly, the present study sought to extend the scope of collaborative writing studies to FL context. More specifically, it aimed to investigate the writing performance of Iranian intermediate EFL learners in the textbook evaluation course which is one of the university courses for the students of TEFL (Teaching English as a Foreign Language). For this purpose, fifty seven female EFL learners participated in this study. It was carried out in two parallel textbook evaluation classes; namely, control and experimental groups to which students were randomly assigned. Students were supposed to evaluate eight series of ELT materials and write reports based on them. Students in the control group did the tasks individually; whereas students in the experimental group wrote collaboratively in small groups. Data collection was based on the pre-test, post-test design. The results of statistical analysis revealed that the students working in groups outperformed those writing individually based on such writing components as content, organization, grammar, and vocabulary.
\end{abstract}

Index Terms - individual writing, collaborative writing, writing reports

\section{INTRODUCTION}

It is generally believed that writing is an individual activity often followed by feedback; However from the social constructivist perspective of language learning, based on the work of Vygotsky (1978), learners' early attempts at writing are grounded in speech. Therefore, development of written language is best fostered by a supportive conversational environment. So, it seems that our understanding of writing including first language (L1), second language (L2), and foreign language (FL) has started to shift away from a completely individualistic perspective to a sociocultural one.

Researchers inspired by the sociocultural theory of language learning have been encouraged to investigate the role of language itself in the process of L2 or FL learning. Specifically, they have focused on oral interaction and how it is used in learning activities. The effects of spoken interaction within L2 writing classroom is a topic of growing interest among L2 writing researchers. Weissberg (2006) claims that social interaction provides an ideal context for mastering complex cognitive skills like writing, and these two should not be separated. In this post-process era of writing(Atkins, 2003, p.6) quality writing requires both cognitive and social skills.

According to Vygotsky (1978), scaffolding enables children to stretch their cognitive and language development beyond their current level towards their potential level of development. Research has shown that such scaffolding can also occur in L2/FL context among peers working in pairs or groups (Kim, 2008; Nassaji \& Tian, 2010; Storch 2002; Swain, 2010; Swain \& Lapkin, 2002; Weissberge, 2006; Shehadeh, 2011; Dobao, 2012; Wigglesworth \& Storch, 2009; Hubert, 2011). Collaborative writing (CW) provides learners with the opportunity to engage with language and test their hypothesis. The learner's attempt to solve language problems is referred to as "languaging" by Swain $(2006,2010)$. When learners work on their own, languaging is self-directed; but when learners work together languaging refers to the social construction of meaning through talk about language which may involve discussions of aspects of language itself. Languaging in the context of writing provides learners with the opportunity to focus on language problems (Swain, 2006).

Despite the growing interest in cross-modality research, to use Weissberg's terminology (1994), this field suffers from a series of shortcomings. One of the most important one is the fact that researchers and practitioners are still not sure if oral interaction in L2 writing classroom has any positive effects on writing product or process since research done so far revealed contradictory results in this regard. According to Wigglesworth and Storch (2012), much more research is required to develop our understanding of how collaborative writing activities and collaborative engagement with feedback can enhance language learning. On the other hand, most cross-modality research has focused on ESL students and ignored foreign language learners (Hubert, 2011). 
The majority of foreign language majors, like EFL curricula, require students to complete at least on intermediate/advanced-level composition course. Courses like these usually consist of grammatical instruction, paragraph development and essay writing. They commonly follow an individualistic, instructor-centered approach in which students write their composition outside class, leaving the class time to explicit grammatical or rhetorical instruction. In order to extend the scope of these studies to FL context and provide more evidence on the effectiveness of $\mathrm{CW}$, the present study tries to investigate the effect of small group task-based collaborative writing activities on Iranian EFL learners' writing quality.

\section{LITERATURE REVIEW}

A large body of research has examined the interaction of oral and written language in formal educational context based on Vygotskian notion of social interaction (1978). L2 practitioners and researchers have also taken up the interactionist approach and stressed the need for L2 composition teachers to promote a social atmosphere in the classroom. Cumming (1992) focused on the discourse organization of English as a second language (ESL) composition lessons. One of the routines followed in such classes in particular is "collectively constructing interpretations" in which teachers led open-ended discussions, promoting "interactive and responsive" talk among class participants. (p.25). For L2 learners, classroom talk takes on importance from both social interactionist and cognitive perspectives. According to Weissberg (1994), L2 writers may benefit from the use of talk to explore topics for composition, to encode ideas linguistically, and to become aware of aspects of writing process. Collaborative writing projects, peer editing groups, and conferencing have been suggested as ways of injecting oral interaction into the writing class (Manglesdorf, 1989).

Despite the fact that ESL writing classroom has traditionally been a place of individual work supervised by an expert teacher, researchers applying sociocultural theory to the study of L2 learning maintain that learners can have a positive impact on each other's development because they can act as both novices and experts since no two learners have the same strength and weaknesses (Donato, 1994; Ohta, 2001; Storch, 2002). They can provide scaffolded assistance to each other, and by sharing different resources achieve a level of performance that is beyond their individual level of competence (Ohta, 2001). However, not all pair or group work is collaborative. Donato (2004, p. 287) argues that interaction is only collaborative under certain conditions:

- Participants must have developed social relations as a result of their joint work which should include a meaningful core activity;

- Participants must acknowledge themselves as apart of core activity in such a way that each individual has a role to play in achieving a larger goal;

- Participants must possess knowledge which can be shared with other participants in order to construct new knowledge through which group coherence can develop.

Studies that have used collaborative writing as a means to explore the effects of task variables on language output and language learning tend to have a pedagogical orientation examining the forms that would be focused on during different task conditions. A number of studies have investigated the effects of collaboration on writing product. For example, Storch and Wigglesworth (2007) compared writing performance on two tasks by learners working either in pairs or individually. They found a significance difference between the two groups in terms of accuracy but not on measures of fluency and complexity. In a related study on the same data, Wigglesworth and Storch (2009) examined the transcripts of learners' pair talk to identify the role collaboration and interaction played in composing sentences. They found that brainstorming of ideas took up the greatest proportion of time and included making notes about ideas. Revision with a focus on grammatical accuracy and lexical choice was also important as learners discussed their use of language.

Dobao (2012) investigated the performance of intermediate Spanish learners in a university context. There were three groups of learners working in groups, pairs or individually to complete a written task following a lesson reviewing past tense grammar. The interactions of groups and pair works were recorded, transcribed and analyzed for accuracy, fluency and complexity (syntactic and lexical). The results revealed that groups produced the most accurate texts followed by pairs and then individuals. The groups produced a larger number of LREs (language related episodes) than pairs. The results suggest that pooled knowledge act as an enabler in collaborative writing activities allowing learners to produce more accurate texts.

Reichelt (1999) has suggested that FL learners lack truly extrinsic motivation engaging in FL composition writing. Although writing assignments of university FL courses may provide a certain measure of extrinsic motivation, they are usually given when there is no clear audience or purpose for writing outside the FL classroom (p.195). In-class peer collaboration on writing projects may indeed help FL writers to develop a sense of audience which may help to fill this information gap in FL writing. Shehadeh (2011) extended the study of collaborative writing into the foreign language classroom. In this longitudinal study conducted over a 16-week semester based on a re-test posttest design, learners worked either individually or in pairs and were asked to complete a series of writing tasks on which they were given oral and written feedback. The results revealed improvement in content, organization and vocabulary but not in grammatical accuracy. As Shehadeh argues, this could be related to low-proficiency level of learners and the fact that they may have not the necessary language knowledge to help each other. 
In another attempt to expand the scope of CW to FL context, Biria and Jafari (2013) investigated the impact of CW on the writing fluency of Iranian EFL learners at intermediate level. The study consisted of two phases: instruction and writing. In the instructional phase, paragraph development and essay writing were taught to students. Results revealed that there was a considerable improvement in the use of T-units and clauses produced by pairs; however, the fluency of written texts produced by both groups of individuals and pairs were not significantly different on measures of fluency. In the same context, Marzban and Sarjami (2014) studied the impact of collaborative negotiated feedback on Iranian intermediate EFL learners' writing and compared it with teacher-written feedback. Students were asked to participate in correction of errors. The gain scores of students on post test provided positive evidence in support of the efficacy of collaborative negotiated feedback.

So far, most socioculturally driven research on L2 or FL writing has focused on collaborative writing tasks performed in pairs or groups and compared them with individual writing tasks; however, the results are contradictory. Some provided positive evidence supporting the efficacy of $\mathrm{CW}$, while others indicated little or no effect. It may be concluded that the efficacy of CW is influenced by other variables like context of learning whether L2 or FL; the nature of tasks; learners grouping, whether in pairs or small groups; proficiency level of participants; time restriction for performing tasks; the presence or absence of instruction on grammar and writing rhetorics; the nature of feedback, data collection procedures; and measuring scales. Another issue requiring discussion is that it cannot be expected that an activity taking place within a single task administration would necessarily have an immediate feedback on learners' abilities. Moreover according to Ellis (2003), the same task can result in very different kinds of activities when performed by different learners. Last but not least, all research done to date focused on learners' performance in writing classrooms whether in FL or L2 context. Obviously, writing is a necessary skill highly required in other academic courses which can provide more opportunities for learners to improve this skill. The utility of CW in such situations have been ignored.

\section{Statement of the Problem}

The present study is an attempt to add more empirical evidence to our understanding of the effects of collaboration on writing performance of Iranian FL learners. In addition to extending the scope of CW studies to FL context, it focuses on an academic course which its immediate goal is not writing instruction. Specially, it focuses on the writing performance of learners in the textbook evaluation course which is one of the university courses for the students of TEFL (Teaching English as a Foreign Language). Writing reports is one of the requirements of the course which seems to be a challenge for these learners. In other words, this study tries to find out whether the integration of collaborative writing tasks will improve the quality of writing in terms of content, organization, grammar, vocabulary, and mechanics of writing. The research questions that guide the study are:

1. Do small group collaborative writing tasks help Iranian intermediate EFL learners to write more effectively?

2. Are there any differences between the reports produced by individuals and those written by groups?

3. Which aspects of writing are improved through CW?

It is hypothesized that collaboration will help FL learners to improve their writing performance more effectively. This hypothesis is based on two assumptions: a) the provision of immediate audience and interaction will help students to make their writing more accurate and comprehensible to the reader since they are provided with a more authentic reason to write; b) sharing their linguistic and non linguistic resources, groups are able to produce more accurate texts.

\section{METHOD}

\section{A. Participants}

Fifty seven female EFL learners participated in this study. They were juniors ( $3^{\text {rd }}$ year students) at a large public university in Iran. Their field of study was TEFL (Teaching English as a Foreign Language). They ranged in age from 20-26 years old. All participants shared the same $\mathrm{L}_{1}$ background, Persian. They have been admitted to university based on national university entrance examination. Based on the results of the OPT (Oxford Placement Test), they were at the intermediate level of proficiency in English. They were accustomed to teacher-centered instruction, memorization and individual work in their previous learning experiences. At the time of the study, they had enrolled in Textbook Evaluation course as part of the required courses to get their BA degree in TEFL. The study was carried out in fall semester of 2013. Participants were randomly assigned to two groups; namely, control and experimental. 29 students were in control group, and 28 in the experimental one which were divided into 7 groups of 4 students.

\section{B. Materials}

Six sets of materials were implemented in this study including the OPT, a textbook evaluation checklist, 8 series of ELT materials, students reports (pre-test and post-test writing tasks), an analytic writing scale for rating the reports, and the SPSS software for statistical analysis of the data. First of all, the OPT was utilized to find out the current proficiency level of learners. Secondly, students were provided with a checklist for textbook evaluation. It was designed by Daoud, A.M and Celce-Murcia, M. (1979). The checklist consisted of five sections: a) subject matter, b) vocabulary and structures, c) exercises, d) illustration, and e) physical make-up. Each of the five sections is composed of a series of 
questions to be answered based on a 5-point scale ranging from totally lacking (0) to excellent (4). Thirdly, Students were supposed to evaluate 8 series of ELT materials including: 1. Local ELT materials taught at Iranian high schools, 2.Let's go, 3. Bravo, 4. Parade, 5. English Time, 6. Interchange, 7. Headway, and 8. English File series. Next, they were asked to write 8 reports respectively based on the textbook evaluation results of those ELT materials. Since this was a study with pre-test, post-test design, two sets of data were collected from control (no: 58) and experimental (no: 56) groups which yield a total number of 114 reports, 57 reports for pre-test and 57 for post-test. Then, samples of pre-test, and post-test were rated based on the analytic writing scale developed by Hedgcock and Leftkowitz (1992). The scale defines the following 5 components on a 0-100 point scale. There are four specified levels for each component (very poor, fair to poor, good to average, excellent to very good):

- Content: knowledge of subject; development of thesis; converge of topic; relevance of details; substance; quality of details (30 points).

- Organization: fluency of expression; clarity in the statement of ideas; support; organization of ideas; sequencing and development of ideas (20 points).

- Grammar: accurate use of sentence structures and constructions; accuracy and correctness in the use of agreement, number, tense, word order, articles, pronouns, prepositions, negation (25 points).

- Vocabulary: range; accuracy of word/idiom choice; mastery of word forms; appropriateness of register, effectiveness in the transmission of meaning (20 points).

- Mechanics of writing: conventions of spelling, punctuation, capitalization, paragraph indentation (5 points).

Finally, the statistical data analysis was carried out by SPSS software which will be fully elaborated in the data analysis section.

\section{Procedures}

The study was carried out in two parallel textbook evaluation classes (4hrs/week); namely, control and experimental groups to which students were randomly assigned. During the first half of the semester ( 8 sessions), students receive instruction on curriculum and syllabus design, materials development and textbook evaluation for implementation. During the next half of the semester (the remaining 8 sessions), students were supposed to analyze and evaluate 8 series of different ELT materials based on the evaluation checklist developed by Daoud, A. M. and Celce-Murcia, M. (1979) and write a report. The first and the last reports were related to pre-test and post-test. The instruction and writing prompts were exactly the same for both classes. Both classes were taught by the same female teacher. She held an MA in TEFL and has taught TEFL courses for 10 years. In both classes, students received oral and written feedback from the teacher on their final drafts. In addition, they were allowed to have oral conferences with the teacher in the process of wiring. Based on the OPT results, all students were at the intermediate level of proficiency.

There were 29 students in the control group. They were allocated 3 hours to do all the tasks individually during the class time. There were 28 students in the experimental group which were divided into seven groups of four. Since all of them were at intermediate level of proficiency, they were allowed to choose their peers themselves. It was believed that the friendly interpersonal relationships among them would enhance small group work which was a completely new experience for them. They were asked to perform all the tasks collaboratively during 4 hours of class time which includes analyzing and evaluating the textbooks, drafting, revising and writing the final reports. In order to increase the motivation for collaboration, the same score was assigned to all members of the group since they had to deliver one joint report.

Time duration for task performance was based on the number of activities which includes analyzing and evaluating the textbooks based on the checklist, preparing the first draft of the report, and revising it to write the final draft. Experimental group was allocated with more time. According to Storch (2005), they need more time to perform the tasks collaboratively.

This study was based on the pre-test, post-test design. For pre-test, students in both groups were asked to evaluate the local ELT materials which are taught at Iranian high schools: English Book1-3, and write a report based on that during 3 hours of class time. The collected data were rated blindly by two raters (none of whom was the researcher or the teacher) based on the writing scale developed by Hedgcock and Leftkowitz (1992). The researcher met with the instructor and the two raters, explained the purpose of the study and the rating scale. As piloting, the two raters independently rated two sample reports none of which were related to pre-test or post-test. All differences were discussed and resolved and a high level of agreement was reached. The inter-rater reliability for pre-test was established at .79. During six session, students in both groups have performed textbook evaluation tasks on Let's go, Bravo, Parade, English Time, Interchange and Headway series. Then the post-test was conducted with the same procedure. The students in both groups analyzed and evaluated the English File series and wrote their reports during 3 hours of class time. The data of post-test were rated blindly by the same two raters, and the inter-rater reliability for post was .82 .

\section{Data Analysis AND Results}

As mentioned before, the present study aimed at investigating the effects of collaborative writing tasks on the writing quality of Iranian intermediate EFL learners in terms of content, organization, grammar, vocabulary, and mechanics of 
writing. In order to answer the research questions, two independent sample t-tests were carried out for pre-test and posttest respectively.

Table I shows descriptive statistics for pre-test. It shows mean value, standard deviation and standard error of mean for all writing components regarding control and experimental groups. Comparing the data in table I with the level specifications in the rating scale (see appendix A), it becomes clear that learners in both groups were at fair to poor level. The mean value for total score of the control group is 62.21, and it is 62.45 for experimental group. That is, students in both groups showed: limited knowledge and minimal thematic development(content); loose connection and sequencing of ideas (organization); significant problems in use of complex structures, frequent errors in agreement, number, tense, word order, and prepositions (grammar); limited range of vocabulary, inappropriate word choice, frequent translation-based problems (vocabulary); and frequent spelling punctuation, capitalization errors (mechanics).

TABLE I.

DESCRIPTIVE STATISTICS FOR PRE-TEST

\begin{tabular}{|l|l|l|l|l|l|}
\hline Variables & Groups & $\mathrm{N}$ & Mean & Std. Deviation & Std. Error Mean \\
\hline Content & Control & 29 & 19.00 & 2.04 & .38 \\
& Experimental & 28 & 19.10 & 2.14 & .40 \\
\hline Organization & Control & 29 & 12.93 & 2.51 & .47 \\
& Experimental & 28 & 12.45 & 2.24 & .42 \\
\hline Grammar & Control & 29 & 13.86 & 2.24 & .42 \\
& Experimental & 28 & 14.83 & 2.51 & .47 \\
\hline Vocabulary & Control & 29 & 12.93 & 1.86 & .35 \\
& Experimental & 28 & 12.90 & 1.26 & .23 \\
\hline Mechanics & Control & 29 & 3.50 & .64 & .12 \\
& Experimental & 28 & 3.17 & .66 & .12 \\
\hline Total score & Control & 29 & 62.21 & 7.07 & 1.34 \\
& Experimental & 28 & 62.45 & 7.11 & 1.32 \\
\hline
\end{tabular}

Table II shows the results of independent samples t-tests for pre-test. As expected, there were no significant differences between the two groups regarding all writing components and also the total score on pre-test. The observed significance value (sig. 2-taled) for all writing components and the total score are greater than .05. Moreover, the Levene's Test for equality of variances shows no significant differences since the observed $\mathrm{p}$ values are greater than .05 . Therefore, it can be safely assumed that equal variances exist.

TABLE II.

INDEPENDENT SAMPLES T-TEST FOR PRE-TEST

\begin{tabular}{|c|c|c|c|c|c|c|c|c|c|}
\hline & \multicolumn{2}{|c|}{$\begin{array}{l}\text { Leven's Test for } \\
\text { Equality of Variances }\end{array}$} & \multicolumn{7}{|c|}{ t-test for Equality of Means } \\
\hline & \multirow[t]{2}{*}{$\mathrm{F}$} & \multirow[t]{2}{*}{ Sig. } & \multirow[t]{2}{*}{$\mathrm{t}$} & \multirow[t]{2}{*}{$\mathrm{df}$} & \multirow{2}{*}{$\begin{array}{l}\text { Sig. } \\
\text { (2-tailed) }\end{array}$} & \multirow{2}{*}{$\begin{array}{l}\text { Mean } \\
\text { Difference }\end{array}$} & \multirow{2}{*}{$\begin{array}{l}\text { Std. Error } \\
\text { Difference }\end{array}$} & \multicolumn{2}{|c|}{$95 \%$ Confidence Interval of the Difference } \\
\hline & & & & & & & & Lower & Upper \\
\hline Content & .055 & .816 & -.187 & 55 & .853 & -.10 & .55 & -1.21 & 1.01 \\
\hline Organization & .029 & .866 & .896 & 55 & .374 & .48 & .54 & -.59 & 1.55 \\
\hline Grammar & .820 & .369 & -1.539 & 55 & .130 & -.97 & .63 & -2.23 & .29 \\
\hline Vocabulary & 2.146 & .149 & .076 & 55 & .940 & $3.20 \mathrm{E}-02$ & .42 & -.81 & .87 \\
\hline Mechanics & .412 & .524 & 1.906 & 55 & .062 & .33 & .17 & $-.1 .68 \mathrm{E}-02$ & .67 \\
\hline Total score & .055 & .816 & -.125 & 55 & .901 & -.23 & 1.88 & -4.00 & 3.53 \\
\hline
\end{tabular}

Students performed 6 writing tasks in both groups, and then the post-test was conducted. Table III shows descriptive statistics for post-test. It shows mean value, standard deviation and standard error of mean for all writing components regarding control and experimental groups. As it is clear, both groups improved in their writing ability (compare table I and II).

Comparing the results with level specifications of the rating scale, it is revealed that the control group (individuals) improved to the next level of writing that is called good to average (see appendix A) in all aspects of writing except grammar. That is students who wrote individually gained some knowledge of subject and the content of their reports was mostly related to the topic but lacked details (mean value for content $=22.50$ ). Their reports on the post-test showed adequate fluency with clear main ideas; however, they were loosely organized and had limited supporting materials (mean value for organization= 15.57). Regarding the vocabulary aspect, their texts effectively transmitted meaning; however, they weren't free of word choice errors (mean value for vocabulary= 15.50). Occasional errors were observed in their use of mechanics of writing, but the errors did not interfere with meaning (mean value for organization=4). Finally, their total scores developed from 62.21 (pre-test) to 73.21 (post-test). The only aspect of writing which did not improve was grammar (mean value for grammar=15.71), it was still at fair to poor level.

The case was a little different considering the students who practiced collaborative writing in small groups, since their reports advanced to the excellent to very good level in terms of content $(\mathrm{M}=27)$ and organization $(\mathrm{M}=18.03)$. However, for grammar $(M=18.79)$, vocabulary $(M=16.76)$, mechanics of writing $(M=4.00)$, and total score $(M=84.48)$ their writing quality improved to good to average level based on the writing scale. In other words, their reports were knowledgeable, substantive, and relevant to the assigned topic with clearly stated and logically organized ideas. In terms of grammar, they used simple constructions effectively, but their production of complex structures was somehow 
problematic. Their use of vocabulary was at an adequate range, but not free of word choice errors. Occasional errors were observed regarding mechanics of writing, but they did not interfere with meaning.

TABLE III.

DESCRIPTIVE STATISTICS FOR POST-TEST

\begin{tabular}{|l|l|l|l|l|l|}
\hline Variables & Groups & $\mathrm{N}$ & Mean & Std. Deviation & Std. Error Mean \\
\hline Content & Control & 29 & 22.50 & 2.98 & .56 \\
& Experimental & 28 & 27 & .86 & .16 \\
\hline Organization & Control & 29 & 15.57 & 2.27 & .43 \\
& Experimental & 28 & 18.03 & .94 & .18 \\
\hline Grammar & Control & 29 & 15.71 & 2.29 & .43 \\
& Experimental & 28 & 18.79 & 2.64 & .49 \\
\hline Vocabulary & Control & 29 & 15.50 & 1.84 & .35 \\
& Experimental & 28 & 16.76 & 1.77 & .33 \\
\hline Mechanics & Control & 29 & 4.00 & .67 & .13 \\
& Experimental & 28 & 4.00 & .00 & .00 \\
\hline Total score & Control & 29 & 73.21 & 9.06 & 1.71 \\
& Experimental & 28 & 84.48 & 5.97 & 1.11 \\
\hline
\end{tabular}

In order to answer the second research question, independent samples t-tests were conducted to compare the two groups on post-test. As it is presented in table IV, the results show statistically significant differences between the two groups considering the content $(\mathrm{p}=.000)$, organization $(\mathrm{p}=.000)$, grammar $(\mathrm{p}=.000)$, vocabulary $(\mathrm{p}=.011)$, and total scores $(\mathrm{p}=.000)$. There was no significant difference for mechanics of writing $(\mathrm{p}=1.00)$ at .05 level of significance. It seems that the experimental group outperformed the control group in all aspects except mechanics of writing.

TABLE IV.

INDEPENDENT SAMPLES T-TEST FOR POST-TEST

\begin{tabular}{|c|c|c|c|c|c|c|c|c|c|}
\hline & \multicolumn{2}{|c|}{$\begin{array}{l}\text { Leven's Test for } \\
\text { Equality of Variances }\end{array}$} & \multicolumn{7}{|c|}{ t-test for Equality of Means } \\
\hline & \multirow[t]{2}{*}{$\mathrm{F}$} & \multirow[t]{2}{*}{ Sig. } & \multirow[t]{2}{*}{$\mathrm{t}$} & \multirow[t]{2}{*}{ df } & \multirow{2}{*}{$\begin{array}{l}\text { Sig. } \\
\text { (2-tailed) }\end{array}$} & \multirow{2}{*}{$\begin{array}{l}\text { Mean } \\
\text { Difference }\end{array}$} & \multirow{2}{*}{$\begin{array}{l}\text { Std. Error } \\
\text { Difference }\end{array}$} & \multicolumn{2}{|c|}{ 95\% Confidence Interval of the Difference } \\
\hline & & & & & & & & Lower & Upper \\
\hline Content & .820 & .369 & -7.637 & 55 & .000 & -4.40 & .58 & -5.55 & -3.24 \\
\hline Organization & .029 & .866 & -5.387 & 55 & .000 & -2.46 & .46 & -3.38 & -1.55 \\
\hline Grammar & .357 & .552 & -4.698 & 55 & .000 & -3.08 & .66 & -4.39 & -1.77 \\
\hline Vocabulary & .412 & .524 & -2.638 & 55 & .011 & -1.26 & .48 & -2.21 & -.30 \\
\hline Mechanics & .055 & .816 & .000 & 55 & 1.000 & .00 & .12 & -.25 & .25 \\
\hline Total score & .830 & .385 & -5.564 & 55 & .000 & -11.27 & 2.03 & -15.33 & -7.21 \\
\hline
\end{tabular}

\section{DISCUSSION AND CONCLUSION}

Considering the research questions, results of statistical analysis showed that collaborative writing had an overall significant effect on improving the writing quality of Iranian FL students of TEFL; nevertheless this effect varied from one area to another that is the collaborative group outperformed the individual group in all components of writing except mechanics. In other words, the effect was significant in the areas of content, organization, grammar, and vocabulary but not mechanics of writing. With respect to mechanics of writing, a possible explanation is that there are a relatively limited number of rules and conventions in this regard which can be mastered more easily by students in both groups.

As mentioned in the previous section, quality of students' writing improved totally in both conditions (see table I and II) which is due to the nature of task-based process writing. Table III showed that students who practiced individual writing developed their writing quality regarding all components except grammar. However, this was not the case with collaborative writing group. Their progress was greater regarding the content and organization components. In these two areas, they advance two levels from fair to poor level to excellent to very good based on the rating scale. Another difference was that students in the collaborative group developed their level of grammar from fair to poor level to good to average level. This improvement was observed for the other two components (vocabulary and mechanics) as well. It can be concluded that collaborative writing had a greater effect on the following components of writing: content, organization, and grammar.

Results of this study are in line with social constructivist perspective of learning which claims that CW would improve the quality of students' writing. That is collaboration in all steps of writing including generating ideas, planning, drafting, and revising helped students to share and pool their sources of knowledge to the effect that their writing proficiency was statistically at a higher level in post-test. In other words, CW leads to learning (that is writing to learn). As it was mentioned before, in this study students did not receive any explicit instruction on grammar or composition writing since this research was conducted in a textbook evaluation classroom which is an academic course for the students of TEFL. It can be concluded that providing learners with authentic writing tasks and immediate audience will lead to proficiency improvement even when writing is not the focus of the study. 
Results of this study are compatible with those of Shehadeh (2011) regarding the efficacy of CW in terms of improvement in the areas of content, organization, vocabulary; however, the two studies are contradictory regarding the grammar component. This may be due to the fact that grouping patterns were different in these two studies. In this study CW tasks were performed in groups of four students, while they were performed in pairs in the study done by Shehadeh. In another study done by Jafari and Biria (2013), no significant difference was observed between individual and collaborative (pair work) writing conditions in terms of fluency. But Marzban and Sarjami's (2014) findings revealed the effectiveness of collaborative corrective feedback in which students were working in groups of five. This was also the case for the research done by Dobao (2012) in that learners who worked in groups produced more accurate texts. So, it seems that for intermediate EFL learners, small group collaboration is probably more effective than pair work.

Textbook developers, foreign language learners, and teachers may benefit from the findings of the present study in the following ways: this research provides further empirical evidence on the efficacy of CW for FL writing classrooms and also other academic courses which require writing tasks. Specifically, CW can be used as a pedagogical tool to encourage more classroom interaction among learners where they are accustomed to individual work. This can create a positive social atmosphere in FL classrooms with a sense of immediate audience which can increase students' motivation to participate in writing tasks more effectively. Therefore, $\mathrm{CW}$ is not limited to the writing course but it is possible to apply this activity in other academic courses to help students improve their writing skill through authentic tasks.

This study is not without limitation. If the oral interaction of group members were recorded, it would be possible to find out the main focus of learners' talk during CW tasks. Also it would be possible to investigate whether use of L1 has any effects on task fulfillment of FL learners.

\section{APPENDix A. RATing ScALE}

\begin{tabular}{|c|c|}
\hline & Score Criteria \\
\hline Content & $\begin{array}{l}\text { 27-30 Excellent to very good: knowledgeable; substantive, thorough development of thesis; relevant to topic assigned } \\
\text { 22-26 Good to average: some knowledge of subject; adequate range; limited thematic development; mostly relevant } \\
\text { to topic, but lacks detail } \\
\text { 17-21 Fair to poor: limited knowledge of subject; minimal substance; poor thematic development } \\
\text { 13-16 Very poor: shows little or no knowledge of subject; inadequate quantity; not relevant, or not enough to rate }\end{array}$ \\
\hline Organization & $\begin{array}{l}\text { 18-20 Excellent to very good: fluent expression; clear statement of ideas; solid support; clear organization; logical } \\
\text { and cohesive sequencing } \\
\text { 14-17 Good to average: adequate fluency; main ideas clear but loosely organized; supporting material limited; } \\
\text { sequencing logical but incomplete } \\
\text { 10-13 Fair to poor: low fluency; ideas not well connected; logical sequencing and development lacking } \\
\text { 7-9 Very poor: ideas not communicated; organization lacking, or not enough to rate }\end{array}$ \\
\hline Grammar & $\begin{array}{l}\text { 22-25 Excellent to very good: accurate use of relatively complex structures; few errors in agreement, number, tense, } \\
\text { word order, articles, pronouns, prepositions } \\
18-21 \text { Good to average: simple constructions used effectively; some problems in use of complex constructions; errors } \\
\text { in agreement, number, tense, word order, articles, pronouns, prepositions } \\
11-17 \text { Fair to poor: significant defects in use of complex constructions; frequent errors in agreement, number, tense, } \\
\text { negation, word order, articles, pronouns, prepositions; fragments and deletions; lack of accuracy interferes } \\
\text { with meaning } \\
5-10 \text { Very poor: no mastery of simple sentence construction; text dominated by errors; does not communicate, } \\
\text { or not enough to rate }\end{array}$ \\
\hline Vocabulary & $\begin{array}{l}\text { 18-20 Excellent to very good: complex range; accurate word/idiom choice; mastery of word forms; appropriate register } \\
\text { 14-17 Good to average: adequate range; errors of word/idiom choice; effective transmission of meaning } \\
\text { 10-13 Fair to poor: limited range; frequent word/idiom errors; inappropriate choice, usage; meaning not effectively } \\
\text { communicated } \\
7-9 \text { Very poor: translation-based errors; little knowledge of target language vocabulary, or not enough to rate }\end{array}$ \\
\hline Mechanics & $\begin{array}{l}5 \text { Excellent to very good: masters conventions of spelling, punctuation, capitalization, paragraph indentation, etc } \\
4 \text { Good to average: occasional errors in spelling, punctuation, capitalization, paragraph indentation, etc., } \\
\text { which do not interfere with meaning } \\
3 \text { Fair to poor: frequent spelling, punctuation, capitalization, paragraphing errors; meaning disrupted by } \\
\text { formal problems } \\
2 \text { Very poor: no mastery of conventions due to frequency of mechanical errors, or not enough to rate }\end{array}$ \\
\hline
\end{tabular}

Source: Hedgcock, J., \& Lefkowitz, N. (1992). Collaborative oral/aural revision in foreign language writing instruction. Journal of Second Language Writing, 1(3), 275-276. Reproduced with permission of the authors.

\section{ACKNOWLEDGMENT}

The authors wish to thank the instructor, the two raters and all the learners who participated in this study. We would also like to thank the two anonymous reviewers and editors of TPLS journal for reading earlier drafts of this article and providing valuable comments and feedback.

\section{REFERENCES}

[1] Atkinson, D. (2003). L2 writing in the post-process era: Introduction. Journal of Second Language Writing 12, 3-15. 
[2] Biria, R. \& S. Jafari. (2013). The impact of collaborative writing on the writing fluency of Iranian EFL learners. Journal of Lnaguage Teaching and Research. 4.1, 165-175.

[3] Cumming, A. (1992). Instructional routines in ESL composition teaching: A case study of three teachers. Journal of Second Language Writing 1, 17-35.

[4] Daoud, A.M. \& M. Celce-Murcia. (1979). Selecting and evaluating a textbook. In M. Celce-Murcia \& I. McIntosh (eds.) Teaching English as a second or foreign language. USA: Thomson Learning, 302-307.

[5] Dobao, A. (2012). Collaborative writing tasks in the L2 classroom: Comparing group, pair, and individual work. Journal of Second Language Writing 21, 40-58.

[6] Donato, R. (1994). Collective scaffolding in second language learning. In J.P. Lantolf \& G. Appel (eds.) Vygotskian approaches to second language research, 33-56. Norwood. NJ: Ablex.

[7] Donato, R. (2004). Aspects of collaboration in pedagogical discourse. In Annual review of applied linguistics, Cambridge: CUP, 284-302.

[8] Ellis, R. (2003). Task-based language learning and teaching. Oxford: OUP

[9] Hedgcock, J. \& N. Leftkowitz. (1992). Collaborative oral/aural revision in foreign language writing instruction. Journal of Second Language Writing1.3, 275-276.

[10] Hubert, M. (2011). The speaking-writing connection: Integrating dialogue into a foreign language writing course. Electronic Journal of Foreign Language Teaching 8.2, 170-183.

[11] Kim, Y. (2008). The construction of collaborative and individual tasks to the acquisition of L2 vocabulary. The Modern Language Journal 92, 114-130.

[12] Kuiken, F. \& I. Vedder. (2002). The effect of interaction in acquiring the grammar of a second language. International Journal of Educational Research 37, 343-358.

[13] Manglesdorf, K. (1989). Parallels between speaking and writing in second language acquisition. In D. Johnson \& D. Roen (eds.) Richness in writing: Improving ESL students. London: Longman.

[14] Marzban, A. \& Sh. Sarjami. (2014). Collaborative negotiated feedback versus teacher-written feedback: Impact on Iranian intermediate EFL learners' writing. Theory and Practice of Language Studies 4.2, 293-302.

[15] Nassaji, H. \& J. Tian. (2010).Collaborative and individual output tasks and their effects on learning English phrasal verbs. Language Teaching Research 14, 397-419.

[16] Shehadeh, A. (2011). Effects and students perception of collaborative writing in L2. Journal of Second Language Writing 20, 286-305.

[17] Storch, N. \& G. Wigglesworth. (2007).Writing tasks: the effect of collaboration. In M.P. Garcia Mayo (ed.) Investigating tasks in foreign language learning, 157-177. Cleve don: Multilingual Matters.

[18] Storch, N. (2002). Patterns of interaction in ESL pair work. Language Learning 52, 119-158.

[19] Swain, M. (2006). Languaging, agency and collaboration in advanced language proficiency. In H. Byrenes (ed.) Advanced Language Learning: The contribution of Halliday and Vygotsky. New York: Continuum, 95-108.

[20] Swain, M. (2010). Talking-it-through: Languaging as a source of learning. In R. Bastone (ed.) Sociocognitive perspectives on language use/learning. Oxford: OUP, 112-130.

[21] Vygotsky, L. (1978). Mind in society. Cambridge, MA: Harvard University Press.

[22] Weissberg, B. (1994). Speaking of writing: Some functions of talk in the ESL composition class. Journal of Second Language Writing 3.2, 121-139.

[23] Weissberg, B. (2006). Connecting speaking and writing in second language writing instruction. Arbor: University of Michigan Press

[24] Wigglesworth, G. \& N. Storch. (2009). Pair versus individual writing: effects of fluency, complexity and accuracy. Language Testing 26, 450-466.

[25] Wigglesworth, G. \& N. Storch (2012). What role for collaboration in writing and writing feedback. Journal of Second Language Writing 21, 364-374.

[26] Ohta, A.S. (2001). Second language acquisition processes in the classroom: Learning Japanese. Mahwah, NJ: Lawrence Erlbaum.

[27] Reichelt, M. (1999). Toward a more comprehensive view of L2 writing: Foreign language writing in the U.S. Journal of Second Language Writing 85.4, 578-598

[28] Storch, N. (2005). Collaborative writing: product, process and students' reflections. Journal of Second Language Writing 4, 153-173.

[29] Swain, M. \& S. Lapkin. (2002). Talking it through: Two French immersion learners' response to reformulation. International Journal of Educational Research 37, 285-304.

Nafiseh Hosseinpour was born in Isfahan, Iran. She got her BA in TEFL from Kashan University, Kashan, Iran in 2000. She got her MA in TEFL from Islamic Azad University, Khorasgan Branch, Isfahan, Iran in 2003. She is currently a PhD student in Islamic Azad University, Khorasgan Branch. She has been a faculty member of Islamic Azad University, Falavarjan Branch since 2005. Her research interests are teacher education, teaching and learning strategies, and teaching English as a foreign language.

Reza Biria, born in Isfahan, Iran, obtained his Ph.D. in teaching English as a Foreign Language from the University of Isfahan in 2001. He is an applied linguistics assistant professor working at Khorasgan Azad University, Isfahan, Iran. Dr. Biria has published papers in national and international conferences. His research interests include teaching English as a second and foreign lan guage and ESP. 